\title{
Sarcopenia reversible by diet
}

\author{
H Gao-Balch $\mathbf{Y}^{*}$ \\ Department of Human Science, the University of Arkansas at Pine Bluff, 1200 North University Drive, Pine Bluff, Arkansas 71601, USA
}

\begin{abstract}
Optimal health for older people depends on maintaining muscle mass. Science indicated the potential importance of diets of adequate quality, to ensure sufficient intakes of protein, vitamin $\mathrm{D}$, and antioxidant nutrients by the food. Optimizing diet and nutrition throughout life may be vital in preventing sarcopenia and promoting functional ability in older age. Furthermore, nutrition science faces the challenge to design a balanced meal, which includes these nutrients to guarantee daily intake but a supplement.
\end{abstract}

Sarcopenia is a disease associated with aging [1]. This condition cause loss of muscle mass and strength, which affects balance, and overall ability to perform tasks of daily living [2]. What are the factors to impact on muscle loss? Physiological of change with Aging; like hormone decline, unbalance of muscle anabolism and catabolism, protein requirements change, as well become more sedentary of lifestyle [3]. Long-term inflammatory disease can result in the disruption of the healthy balance between teardown and healing processes, the medical conditions that are causing stress on the body $[1,2]$.

Along with Aging, the hormones, cytokines make more human pro-inflammatory and anti-inflammatory cytokines, for example, tumor necrosis factor (TNF), Interleukin (IL)-6, and with increasing C-reactive protein, as evidence of systemic inflammation with Aging [3-5]. More sedentary of lifestyle. Even, periods of decreased activity can become a muscle strength decreases, resulting in more fatigue and making it more challenging to return to regular exercise.

Although some sarcopenias are a natural consequence of Aging, others are preventable. Studies show sarcopenia can be reversed, and muscle loss decreased. A healthy diet and reasonable exercise can reverse sarcopenia, which increases lifespan and improve quality of life.

\section{Three nutrients that fight sarcopenia}

First, Protein of intake to digest and absorption with agingassociated with a progressive decline in the sense of test bud, medical conditions with the teeth, gums and swallowing, or increased difficulty shopping and cooking, a diet is providing low calories and low -protein of eating pattern of result in weight loss and diminished muscle mass [5], lower rates of protein synthesis and whole-body proteolysis in response to an anabolic stimulus [6]. Therefore, protein malnutrition may also play an important role that can make a dramatic difference in muscle function and mass [7].

The optimal health for older people depends on maintaining muscle mass, which requires higher than minimal amounts of dietary protein $[7,8]$. Consuming enough dietary protein directly signals muscle tissue to grow and strengthen. That is why eating more protein is even more critical during the elder years. Whey is the by-product of the liquid remaining after milk has been curdled and strained, that is stimulating of muscle protein synthesis (MPS) to make whey digested more rapidly and to have a higher Leucine content [9]. The amino acid Leucine, which is one of the building blocks of protein, is particularly essential for stimulating muscle growth. There are rich sources of Leucine include whey protein, meat, fish and eggs as well as soy protein isolate.

Dietary guideline for American recommended daily allowance (RDA) or protein, which is only 0.8 grams/kilo/per day dietary protein intake. However, for optimizing physical function with Aging, Nowson and O'Connell recommend a protein intake of to 1.0 to $1.3 \mathrm{grams} / \mathrm{kg} /$ per day with resistance exercise [10].

The second essential nutrient is that Vitamin $\mathrm{D}$, which is the primary function, is cell management. Vitamin $\mathrm{D}$ is a hormone, and its activation in the body requires a functioning liver and kidneys [11]. Vitamin D of deficiency is related to sarcopenia; but the exact reason why is not very well understand. Vitamin D functions have activated the innate and reduce the adaptive immune systems [12]. The less intake of vitamin D is associated with Infectious diseases.

The primary natural source of the Vitamin D is the synthesis of Vitamin D in the skin from per-Vitamin D through a chemical reaction that is dependent on exposure sun (specifically UVB radiation) $[13,14]$. For eradicate rickets, milk was fortified vitamin D providing a dietary source of the vitamin. One cup serving of milk provides one day request. The RDA for vitamin $\mathrm{D}$ was recently revised. New research indicates that people age 1-70 need 15 micrograms per day, and adults over age 70 need 20 micrograms per day. Most of Dietary Reference Intake (DRI)s go down with age, but the DRI for vitamin $\mathrm{D}$ goes up.

The omega -3 fatty acids are beneficial for lowering inflammation levels in healthy people. Consumption of omega-3 fatty acids from seafood reduces blood markers of inflammation such as C-reactive protein, interleukin 6, and TNF alpha [14]. A study of women and men eating a diet and a daily 2 grams of omega-3fish oil supplement combined with resistance training increased muscle strength are

${ }^{\star}$ Correspondence to: Ying $\mathrm{H}$ Gao-Balch, Department of Human Science, University of Arkansas at Pine Bluff, 1200 North University Drive, Pine Bluff, Arkansas 71601, USA, E-mail: gaobalchy@uapb.edu

Key words: sarcopenia, nutrient, functional ability, aging

Received: August 09, 2019; Accepted: August 29, 2019; Published: September 11,2019 
compared without fish oil with resistance training women group, due to the omega- 3 fatty acid have benefits to anti-inflammatory $[15,16]$. Resulting in research has suggested that omega- 3 fatty acids might also signal muscle growth directly.

An omega-3 fatty acid most widely available in oily fish, such those the North Atlantic and the Pacific Oceans including mackerel, salmon, sea bass and halibut, oil fish have around seven times than artificial feeding. Eggs produced by fed a diet with a natural resource contain higher levels of omega-3 fatty acids. Eggs and meat of content with omega -3 of amounted depended on diet feeding. There is no omega -3 fatty acids intake by RDA. The World Health Organization recommends regular fish consumption (1-2 servings per week) as protective against coronary heart disease and ischemic stroke. Sounds of the best way to getting enough to intake omega -3 fatty acids. Whereas, Food and Drug Administration (FDA) has recommended for the safely consume up to a total of 3 grams per day, as well with no more than 2 grams per day from dietary supplements.

\section{Conclusion}

Optimal health of older people depends on maintaining muscle mass. Optimizing diet and nutrition throughout the life cycle is vital in preventing sarcopenia and promoting functional ability in older age. Nutritional science also faces the challenge to design a balanced diet, which includes adequate protein, vitamin $\mathrm{D}$, and omega -3 fatty acids to meet the nutrient requirements of older people.

\section{References}

1. Cruz-Jentoft AJ, Baeyens JP, Bauer JM, Boirie Y, Cederholm T (2010) Sarcopenia: European consensus on definition and diagnosis: report of the European working group on Sarcopenia in older people. Age Ageing 39: 412-423. [Crossref]

2. Cruz-Jentoft AJ, Landi F, Topinková E, Michel JP (2010) Understanding sarcopenia as a geriatric syndrome. Curr Opin Clin Nutr Metab Care 13: 1-7. [Crossref]

3. Biolo G, Cederholm T, Muscaritoli M (2014) Muscle contractile and metabolic dysfunction is a common feature of sarcopenia of aging and chronic diseases: From sarcopenic obesity to cachexia. Journal of Clinical Nutrition 33: 737-748. [Crossref]

4. Roubenoff R (2003) Sarcopenia: effects on body composition and function. $J$ Gerontol A Biol Sci Med Sci 58: 1012-1017. [Crossref]
5. Castaneda C, Charnley JM, Evans WJ, Crim MC (1995) Elderly women accommodate to a low-protein diet with losses of body cell mass, muscle function, and immune response. Am J Clin Nutr 62: 30-39. [Crossref]

6. Pennings B, Groen B, de Lange A, Gijsen AP, Zorenc AH, et al. (2012) Amino acid absorption and subsequent muscle protein accretion following graded intakes of whey protein in elderly men. The American Journal Physiol Endocrinol metabolic 302: 992999.

7. Tang M, McCabe GP, Elango R, Pencharz PB, Ball RO, et al. (2014) Assessment of protein requirement in octogenarian women with use of the indicator amino acid oxidation technique. The American Journal Clinical Nutrition 99: 891-898. [Crossref]

8. World Health Organization (2007) Food and agriculture organization of the United Nations; United Nations University. Protein and Amino Acid Requirements in Human Nutrition; WHO: Genevo, Switzerland, 1-265.

9. Tang JE, Moore DR, Kujbida GW, Tarnopolsky MA, Phillips SM (2009) Ingestion of whey hydrolysate, casein, or soy protein isolate: effects on mixed muscle protein synthesis at rest and following resistance exercise in young men. Journal of Applied Physiology 107: 987-992. [Crossref]

10. Nowson C, O'Connell S (2015) Protein Requirements and recommendations for older people: A Review. Nutrients 7: 6874-6899. [Crossref]

11. Holick MF (2004) Sunlight and vitamin D for bone health and prevention of autoimmune diseases, cancers, and cardiovascular disease. The American Journal of Clinical Nutrition 80: 1678-1688.

12. Lehmann U, Gjessing HR, Hirche F, Mueller-Belecke A, Gudbrandsen OA (2015) Efficacy of fish intake on vitamin D status: a meta-analysis of randomized controlled trials. The American Journal of Clinical Nutrition 102: 837-847. [Crossref]

13. Holick MF, MacLaughlin JA, Clark MB, Holick SA, Potts JT Jr, et al. (1980) Photosynthesis of previtamin D3 in human skin and the physiologic consequences. Journal of Science 210: 203-205. [Crossref]

14. Ciubotaru I, Lee YS, Wander RC (2003) Dietary fish oil decreases C-reactive protein, interleukin-6, and triacylglycerol to HDL-cholesterol ratio in postmenopausal women on. Journal of Nutritional Biochemistry 14: 513-521. [Crossref]

15. Logan,SL, Spriet LL (2015) Omega-3 fatty acid supplementation for 12 weeks increases resting and exercise metabolic rate in healthy community-dwelling older females. PLoS One 10: 12. [Crossref]

16. Smith GI, Julliand S, Reeds DN, Sinacore DR, Klein S, Mittendorfer B (2015) Fish oilderived n-3 PUFA therapy increases muscle mass and function in healthy older adults. The American Journal Clinical Nutrition 102(1): 115-122. [Crossref]

Copyright: (C2019 Gao-Balch YH. This is an open-access article distributed under the terms of the Creative Commons Attribution License, which permits unrestricted use, distribution, and reproduction in any medium, provided the original author and source are credited. 